\title{
Fine to follow-on? Private anti-trust actions in European law
}

\author{
Thomas Thiede $\mathrm{e}^{1,2,3}$
}

Published online: 13 February 2017

(C) The Author(s) 2017. This article is published with open access at Springerlink.com

\begin{abstract}
If an undertaking infringes European or national competition law, the infringers must reckon with a large range of possible sanctions, of both a public law and a private law nature. Regarding the latter, we take note in this paper of anti-trust actions for damages by private claimants, which have become ever more significant in the anti-trust debate. Against a background of divergent developments in the European Member States, the European legislator has adopted Directive 2014/104/ EU (Directive 2014/104/EU of the European Parliament and of the Council of 26 November 2014 on certain rules governing actions for damages under national law for infringements of the competition law provisions of the Member States and of the European Union Text with EEA relevance, OJ 2014 L 349, 1 ff (DADA)), with the aim of facilitating the full compensation of damage suffered by those affected by violations of European or national competition law, and to coordinate public and private enforcement measures. The Member States must implement this Directive into their national systems. This paper gives an overview of the Directive, analyses its most important provisions, and then discusses the international issues raised in cases concerning cross-border anti-competitive activities.
\end{abstract}

\footnotetext{
This article is based on a presentation given at the 3rd China-EU Legal Forum (CELF) which took place at the Supreme Court of Cassation in Rome on 8./9.9.2015. The 3rd CELF was co-organised by the China Law Society, the Bar Association of Rome, the International Institute for the Unification of Private Law (UNIDROIT), the China-EU School of Law at the China University of Political Science and Law and the College of Comparative Law at the China University of Political Science and Law).

$\triangle$ Thomas Thiede

mail@thomasthiede.info;

http://www.thomasthiede.info

1 University of Graz, Graz, Austria

2 European Centre of Tort and Insurance Law (ECTIL), European Law Institute (ELI), Vienna, Austria

3 Present Address: Higher Regional Court, Dortmund, Germany
} 
Keywords Competition law Public and private enforcement - European Directive on Anti-Trust Damages Actions

\section{Introduction}

If an undertaking infringes EU competition rules, namely Art 101, 102 TFEU, ${ }^{1}$ or national competition laws, such as the German Act against Restraints on Competition ${ }^{2}$ or the Austrian Cartel Act $2005,{ }^{3}$ for instance, then it must traditionally reckon with the possibility of public law sanctions. The most important of these-and arguably the one which dominates media coverage in this area-are fines, which may be imposed by the European Commission, or else by the National Competition Authorities (NCAs). ${ }^{4}$

Over the past years, developments in Brussels have been influenced by the change in the office of the European Competition Commissioner: Joaquín Almunia left the office, to be succeeded by Margrethe Vestager. Almunia's legacy is no mean one; his final year brought substantial fines, totalling approximately EUR 1.69 billion, ${ }^{5}$ including a staggering EUR 953 million penalty imposed on six companies for their participation in an automotive ball bearings cartel. ${ }^{6}$ Other notable 2014 penalties included fines on a manufacturer of high-voltage power cables (EUR $302 \mathrm{~m}$ ), ${ }^{7}$ three manufacturers of car seat foam (EUR $114 \mathrm{~m}$ ), ${ }^{8}$ four smart card chip producers (EUR $138 \mathrm{~m}),{ }^{9}$ and several financial services institutions for colluding on Swiss franc interest rate derivatives (EUR $94 \mathrm{~m}){ }^{10}$

There is a basic rule that EU competition law takes precedence (in application) over the anti-trust laws of the European Member States. ${ }^{11}$ However, EU competition law only covers offences that extend, at the least in their impact, beyond the borders of any single Member State, and thus affect the European Single Market. Cartels and abusive practices by undertakings with a dominant market position that do not affect intra-

\footnotetext{
1 Treaty on the Functioning of the European Union (TFEU) OJ 2010 C 83, 47.

2 German Act against Restraints on Competition (Gesetz gegen Wettbewerbsbeschränkungen, GWB) German Federal Law Gazette (dBGB1.) I 2013, 1750 in the version valid on 1.10.2014, dBGB1 I 2014, 1066.

3 Austrian Cartel Act (Bundesgesetz gegen Kartelle und andere Wettbewerbsbeschränkungen Kartellgesetz 2005, KartG 2005) Austrian Federal Law Gazette (öBGBl) I No 61/2005.

4 See no A.Part I.I.A.1.a)i)3, infra.

5 Even this fell short of the 2013 figure, when fines totalled EUR 1.9 bn.

${ }^{6}$ Commission Decision of 19.3.2014 (Case AT.39922-Bearings), Official Journal (OJ) C 238, 23.7.2014, 10-12. Notably, JKETK, a Japanese company, received full immunity for blowing the whistle on the cartel.

7 Commission Decision of 2.4.2014 (Case AT.39610_Power Cables), OJ C 319, 17.9.2014, 10-15.

${ }^{8}$ Commission Decision of 29.1.2014 (Case AT.39801-Foam), OJ C 354, 8.10.2014, 6-9.

9 Commission Decision of 3.9.2014 (Case AT.39574-Smart Card Chips), unpublished.

${ }^{10}$ Commission Decision of 21.10.2014 (Case AT.39924-Swiss Franc Related Derivatives), unpublished. UBS and Barclays received full immunity from prosecution for whistle-blowing on the cartel and cooperating with the Commission, saving them colossal fines of EUR 2.5 bn and EUR $690 \mathrm{~m}$ respectively. Several other banks received substantial reductions in fines for cooperating.

11 Art 3 para 2 (1) Council Regulation (EC) No 1/2003 of 16 December 2002 on the implementation of the rules on competition laid down in Articles 81 and 82 of the Treaty, OJ 2003 L 001, 1-25.
} 
(Member) State trade remain under the jurisdiction of the national legislator and the NCAs. These national competition authorities also handed out enormous fines in recent years against many companies; the German Bundeskartellamt alone clocked up almost EUR 1 billion, ${ }^{12}$ in 2014 fining — among others-beer brewers (EUR 338 million), ${ }^{13}$ sugar producers (EUR 280 million), ${ }^{14}$ and sausage manufacturers (EUR 338 million). ${ }^{15}$ The French Autorité de la concurrence imposed record fines of EUR 1.09 billion, among others against manufacturers of household and hygiene products. ${ }^{16}$ In Austria, the courts had already imposed fines of about EUR 25 million in 2013 based solely on applications by the independent Bundeswettbewerbsbehörde. ${ }^{17}$

Those who engage in anti-competitive activities are, however, not only faced with the possibility of hefty fines and other public law sanctions, but also with civil law consequences, such as court actions brought by other enterprises and other non-state, i.e. private, persons who have sustained losses as a result of such anti-competitive conduct. Besides injunctions, such actions seek compensation for harm sustained due to the offence. The CJEU held as early as 1964, in the Case Costa/ENEL, ${ }^{18}$ that it is not only the Member States which are the legal subjects of the European legal order established by European primary law, but also individuals, who are subject to duties under Community law and of course also have rights under the same law. Hence, it has been established since the 1960s that anti-competitive conduct can trigger an entitlement to compensation on the part of third parties under the European legal system. In 1974, in the Case BRT I, ${ }^{19}$ the CJEU also recognised that the (now) Art 101 and 102 TFEU have direct effect as between individuals, and directly give rise to rights in those persons which must be upheld in the courts of the Member States. Originally, the CJEU-not following the opinion of Advocate General van Gerven ${ }^{20}$-rejected the idea of a compensation claim directly derived from European primary law in 1994 in the Banks Case. $^{21}$ It was only with the suitably-named Courage Case ${ }^{22}$ in 2001 that the

\footnotetext{
12 Bundeskartellamt, online, http://www.bundeskartellamt.de/SharedDocs/Meldung/EN/Pressemitteilungen/ 2014/23_12_2014_Jahresr\%C3\%BCckblick.html?nn=3591568 (31.3.2015).

13 Bundeskartellamt, online http://www.bundeskartellamt.de/SharedDocs/Entschei-dung/DE/Fallberichte/ Kartellverbot/2014/B10-105-11.pdf;jsessionid=DE393BCB2B8E5840ECD494C88D38EE7B.1_cid371?_ blob=publicationFile \&v=1 (31.3.2015).

14 Bundeskartellamt, online http://www.bundeskartellamt.de/SharedDocs/Meldung/EN/Pressemitteilungen/ 2014/18_02_2014_Zucker.html?nn=3591568 (31.3.2015).

15 Bundeskartellamt, online, http://www.bundeskartellamt.de/SharedDocs/Meldung/DE/Pressemitteilungen/ 2014/15_07_2014_Wurst.html (31.3.2015).

16 Autorité de la concurrence, E vom 18.12.2014, 14-D-19, http://www.autoritedelaconcurrence.fr/user/ avisdec.php?numero=14D19 (31.3.2015).

17 Bundeswettbewerbsbehörde, Tätigkeitsbericht 2013 (2014), 37.

18 CJEU 15.7.1964 -6/64, Costa/Enel, ECLI:EU:C:1954:66; cf also CJEU 5.2.1963-26/62, Van Gend \& Loos, ECLI:EU:1963:1.

19 CJEU 30.1.1974-127/73, BRT/SABAM, ECLI:EU:C:1974:6; cf also CJEU 18.3.1997-C-282/95 P, Guérin automobiles/Kommisson, ECLI:EU:C: 1997:159.

${ }^{20}$ Opinion of the Advocate General van Gerven 13.4.1994-C-128/92, Banks \& Co/British Coal Corporation, ECLI:EU:C:1993:860, no 44, 45.

21 CJEU 13.4.1994-C-128/92, Banks \& Co/British Coal Corporation, ECLI:EU:C:1994:130.

22 CJEU 20.9.2001-C-453/99, Courage/Crehan, ECLI:EU:C:2001:465, no 26.
} 
Luxembourg Court revised this position; nowadays it is settled case law that there can be a compensation claim directly based on the TFEU. ${ }^{23}$

Such anti-trust claims for damages are being raised more often before some European Member States' courts; ${ }^{24}$ notably in Germany, ${ }^{25}$ the Netherlands, ${ }^{26}$ and the United Kingdom. ${ }^{27}$ On the other hand, however, it is difficult, if not impossible, to pursue such anti-trust actions in numerous other Member States. ${ }^{28}$ In an Impact Assessment Report, ${ }^{29}$ the European Commission states that as far as it is aware only a little over a quarter of all competition law infringements upheld in Commission decisions from 2006 to 2012 resulted in one or more follow-on actions for damages. ${ }^{30}$ Moreover, so-called stand-alone actions, brought without a breach first being found by a competition authority, are extremely rare. ${ }^{31}$ So far, only a fraction of the damage caused by competition law infringements has resulted in such claims, although the extent of this damage ranges from around EUR 5.6-23.3 billion per year. ${ }^{32}$ Thus the wrongful benefit remains in the hands of the offenders in a clear majority of cases.

Facing this discrepancy in a pivotal policy area of the European Union, it is hardly very surprising that the European legislator has been on the move, first

${ }^{23}$ CJEU 13.7.2006-C-295-298/04, Manfredi, ECLI:EU:C:2006:461, no 61; CJEU 14.6.2011-C-360/ 09, Pfleiderer, ECLI:EU:C:2011:389; CJEU 6.11.2012-C-199/11, Otis uA, ECLI:EU:C:684, no 40; CJEU 6.6.2013 - C-536/11, Donau Chemie, ECLI:EU:C:2013:366, no 21.

${ }^{24}$ Cf Cortese, Private Antitrust Enforcement-Status Quo in Italy, EuZW 2012, 730; Garzaniti/ Vanhulst/Oeyen, Private Antitrust Enforcement-Status Quo in Belgium, EuZW 2012, 691; KoflerSenoner/Siebert, Die private Durchsetzung von kartellrechtlichen Ansprüchen-Status Quo in Österreich, EuZW 2012, 650; Makatsch/Mir, Die neue EU-Richtlinie zu Kartellschadensersatzklagen-Angst vor der eigenen „Courage“? EuZW 2015, 7; Motyka-Mojkowski, Die private Kartellrechtsdurchsetzung-Status Quo in Polen, EuZW 2012, 817; Vogel, Die private Durchsetzung des Kartellrechts-Status Quo in Frankreich, EuZW 2012, 897; Vollrath, Das Maßnahmepaket der Kommission zum wettbewerbsrechtlichen Schadenersatzrecht, NZKart 2013, 434.

25 Cf $\S 33$ GWB. Naturally, nowhere near all of the issues raised by private actions based on competition law breaches have been resolved in Germany either, cf e.g. Regional Court (LG) of Düsseldorf 17.12.2013, 37 O 200/09, BB 2014, 149; Alexander, Wege und Irrwege-Europäisierung im Kartell- und Lauterbarkeitsrecht, GRUR Int 2013, 636, Zöttl/Schlepper, Die private Durchsetzung von kartellrechtlichen Schadensersatzansprüchen-Status Quo in Deutschland, EuZW 2012, 573.

${ }^{26}$ Cf Commission, Impact Assessment Report, COM(2013) 404 final = SWD(2013) 204 final (hereinafter Impact Assessment Report) no 52; Kortmann/Swaak, Private Antitrust Enforcement-Status Quo in the Netherlands, EuZW 2012, 770; Makatsch/Mir, EuZW 2015, 7; Mederer, Richtlinienvorschlag über Schadenersatzklagen im Bereich des Wettbewerbsrechts, EuZW 2013, 847 (848).

27 Cf sec 47A Competition Act 1998. In the light of schedule 8 Draft Consumer Rights Bill, further changes favourable to private claimants can be anticipated in the Competition Act 1998 and Enterprise Act 2002; with respect, for example, to the status of the Competition Appeals Tribunal (CAT) as the main court for private anti-trust actions. Koch/Thiede, ETL 2014, no 2 Fn 13; Peyer, Die private Durchsetzung von kartellrechtlichen Ansprüchen-Status Quo in England und Wales, EuZW 2012, 617.

${ }^{28}$ Cf even just the critical assessment by Mäsch, Private Ansprüche bei Verstößen gegen das europäische Kartellverbot-,Courage“ und die Folgen, EuR 2003, 825 (823).

29 Commission, Impact Assessment Report, SWD(2013) 204 final.

30 In 15 out of 54 Cases, Commission, Impact Assessment Report SWD(2013) 204 final, no 52.

31 Mederer, EuZW 2013, 847 (848); Urlesberger/Ditz, CJEU overturns Austrian rule on access to files in anti-trust proceedings, ÖZK 2013, 135 (138).

32 Commission, Impact Assessment Report SWD(2013) 204 final, no 67, 102, 172. 
publishing a green paper in $2005,{ }^{33}$ followed by a white paper in $2008{ }^{34}$ A mere 5 years later, in July 2013, the European Commission adopted a whole package of measures; the centrepiece of these was the Proposal for a Directive of the European Parliament and of the Council on certain rules governing actions for damages under national law for infringements of the competition law provisions of the Member States and of the European Union. ${ }^{35}$ Parallel to this, the European Commission issued a communication on the most common economic methods for quantifying anti-trust damages when compensation claims are brought subsequent to competition law breaches, ${ }^{36}$ supplemented by a Recommendation for collective legal protection ${ }^{37}$ as well as a comprehensive 'Practical Guide'. ${ }^{38}$

The EU Council of Ministers passed the draft Directive on 10.11.2014, ${ }^{39}$ the European Parliament also approved the proposal and the President of the European Parliament signed the Directive on 26.11.2014. Now the ball is in the Member States' court. They must transpose this Directive on certain rules for actions for damages under domestic law based on breaches of competition law provisions of the Member States and the EU (hereinafter: Directive on Anti-Trust Damages Actions or DADA) into national law within 2 years of its coming into force, ${ }^{40}$ i.e. by 27.12 .2016 .

\footnotetext{
33 Commission, Green Paper, Damages actions for breach of the EC antitrust rules, COM(2005) 672 final.

34 Commission, White Paper on damages actions for breach of the EC antitrust rules, COM(2008) 165
} final.

35 Commission, Proposal for a Directive of the European Parliament and of the Council on certain rules governing actions for damages under national law for infringements of the competition law provisions of the Member States and of the European Union, COM(2013) 404 final, cf from among the (abundant) literature on the proposal, and with further references: Fiedler, Der aktuelle Richtlinienvorschlag der Kommission-der große Wurf für den kartellrechtlichen Schadenersatz? BB 37/2013, 2179; Fiedler/ Huttenlauch, Der Schutz von Kronzeugen- und Settlementerklärungen vor der Einsichtnahme durch Dritte nach dem Richtlinien-Vorschlag der Kommission, NZKart 2013, 350; Howard, Too little, too late? The European Commission's Legislative Proposals on Anti-Trust Damages Actions, JECLAP 2013, Vol 4, No 6, 455; Koch/Thiede, European Union in: Karner/Steininger (ed) European Tort Law (ETL) 2013 (2014) 699, no 3; Pfeffer/Rummel, Die Zukunft privater Schadenersatzklagen nach dem Richtlinienentwurf der Kommission vom 11.06.2013, WuW 02/2014, 172; Polster/Steiner, Zur Passing-on defense im österreichischen Kartellschadenersatzrecht, ÖZK 2014, 43; Mederer, EuZW 2013, 847 ff; Rittenauer/ Brückner, Sonderschadenersatzrecht für Kartellgeschädigte, wbl 2014, 301; Schuhmacher, Schadenersatzklagen im Wettbewerbsrecht-der Richtlinienvorschlag der Kommission, ecolex 2014, 193; Schwab, Finding the Right Balance-the Deliberations of the European Parliament on the Draft Legislation Regarding Damage Claims, JECLAP, 2014, Vol 5, No 2, 65; Steiner, Der neue RL-V der Kommission zum Private Enforcement, ecolex 2013, 1000; Weitbrecht, Schadenersatzansprüche der Unternehmer und Verbraucher wegen Kartellverstößen, NJW 2012, 881.

36 Commission, Communication from the Commission on quantifying harm in actions for damages based on breaches of Article 101 or 102 of the Treaty on the Functioning of the European Union Text with EEA relevance, OJ 2013 C 167, 19.

37 Commission, Recommendation on Common Principles for Injunctive and Compensatory Collective Redress Mechanisms in the Member States concerning Violations of Rights granted under EU Law, OJ 2013 L 201, 60.

38 Commission, Practical Guide on quantifying harm in actions for damages based on breaches of Article 101 or 102 of the Treaty on the Functioning of the European Union, SWD(2013) 205.

39 Poland, Slovenia and Germany declined to vote in the Council at the time due to dissatisfaction with the rules on joint and several liability (cf no 40, infra), cf Council Document 14680/14 ADD $1=2013$ / 0185 (COD).

40 Art 23 Directive. 


\section{Typical cases}

In practice, the most common type of case, which is also used as the basis for this paper, runs as follows: commercial undertakings in a certain field have engaged in anti-competitive activities over years. They have made horizontal ${ }^{41}$ or vertical arrangements $^{42}$; or, alternatively, one or more businesses with a dominant market position has abused its power in an anti-competitive fashion ${ }^{43}$ so as to obtain higher prices than would in all likelihood be achieved were competition undistorted. The cartel has been discovered by a competition authority or (more likely) one of the cartel members has blown the whistle; the members of the cartel have been fined heavily by the competition authority. ${ }^{44}$ The majority of the undertakings that participated in the activities have admitted this in the course of the proceeding before the relevant authority in order to be eligible for leniency programs or to benefit from other bonus rules.

\section{An overview of the Directive}

The legal basis for the DADA is Art 103 TFEU (competition) and 114 TFEU (Common Market). This double basis was necessary because-as explained above-the harmonisation of the rules of the Member States in this respect concerns both actions for damages based on breaches of EU competition law and on breaches of national law; Art 103 TFEU would not have been sufficient as a basis for the harmonisation of national laws. ${ }^{45}$

Methodologically speaking, the DADA is very obviously based on the idea of creating a uniform European approach while at the same time trying to avoid any unnecessary interference with national procedural and liability rules. The primary aim of the DADA is to give victims effective means of recourse to obtain full compensation for the actual loss they have suffered, as well as any loss of profit, including interest. ${ }^{46}$ Naturally, such full compensation is nothing new; the same was already set out by the CJEU in the Manfredi Case. ${ }^{47}$ Besides creating the means to bring actions for damages, the DADA is also intended to promote consensual dispute resolution. ${ }^{48}$

\footnotetext{
41 This includes, for instance, specific practices such as the formation of cartels, collusion, conspiracy, mergers, predatory pricing, price discrimination and price-fixing agreements. See references in no 21, infra and Rittenauer/Brückner, Der Richtlinienvorschlag der Europäischen Kommission zu Schadenersatzklagen im Kartellrecht, wbl 2014, 303 (309).

42 This includes practices such as exclusive dealing, geographic market restrictions, refusal to deal/sell, resale price maintenance and tied selling.

43 For example, with strategies to impede or exploit competitors and suppliers.

$44 \mathrm{Cf}$ references in no 2, supra. For the question at issue here, it is of no relevance whether the proceedings took place before the Commission or the national competition authority. Weitbrecht, NJW 2012, 881 (881).

45 Cf Recitals 8, 9 DADA.

46 Art 4; Art 2 (2) DADA; Recital 12 DADA.

47 CJEU 13.7.2006-C-295-298/04, Manfredi, ECLI:EU:C:2006:461.

48 Art 18-19 DADA.
} 
The DADA consists of a total of 24 articles, spread out over an introductory (covering subject matter, scope and definitions) and five further chapters, specifically the disclosure of evidence (chapter II), the effect of national decisions, limitation periods and joint and several liability (chapter III), the passing-on of overcharges (chapter IV), the quantification of harm (chapter V), consensual dispute resolution (chapter VI) and the final provisions on review, transposition, temporal application and entry into force (chapter VII).

From a practical perspective, it is worth noting, in particular, the rules on disclosure of evidence in actions for damages: the parties can obtain competition authorities' evidence and then use this before a court in private law actions. While this is good news for the practitioner, it is clearly problematic for the European Commission and the NCAs; cartels are often only exposed by whistle-blowersoften members of the same cartel. There are specific rules in the DADA to protect whistle-blowers $^{49}$ (and thus maintain the incentive to expose anti-competitive behaviour), which govern the interplay between public and private enforcement of competition law. ${ }^{50}$

\section{The DADA in detail}

\subsection{Who can be sued?}

Under Art 1 para 1 DADA, all undertakings or associations of undertakings (assumed perpetrators of European or national competition law) can be sued; notably, the DADA uses this established European term 'undertaking'. Thus, in accordance with how directives function as set out in Art 288 TFEU, the European term 'undertaking' is introduced into the liability, competition and procedural laws of the Member States. ${ }^{51}$

The CJEU decision in the Case $\mathrm{AkzO}^{52}$ is a good example of how this harmonisation can work well. This case concerned the liability of a parent company for anti-competitive activities by its subsidiary. Until this judgment it was undisputed that liability must be assumed when the parent company has a controlling influence on the subsidiary; the CJEU held then that there is also a rebuttable presumption that when the parent company owns $100 \%$ of the capital in the subsidiary it does exercise a controlling influence on this subsidiary's conduct. Further, the parent company is in particular accountable for the subsidiary's conduct if the subsidiary, despite having separate legal personality, largely follows the instructions of the parent company rather than autonomously determining its own market activities. The decision is of great practical benefit, because in the future parent companies will not be able to avoid civil liability by simply letting their

\footnotetext{
49 Art 6 (6) lit a, Art 11 (4-6) DADA.

50 Recitals 24, 26 and 27 DADA.

51 Kersting, Die neue Richtlinie zur privaten Rechtsdurchsetzung im Kartellrecht, WuW 2014, 564 (565); Makatsch/Mir, EuZW 2015, 7.

52 CJEU 10.9.2009_C-97/08 P, Akzo/Commission, ECLI:EU:C:2009:536, no 59.
} 
subsidiaries become insolvent. Based on this decision, the claimant can recover not only from the assets of the subsidiary, but also from those of the group parent company. 53

\subsection{Standing; passing-on defence}

Art 2 DADA contains a rule on who can bring actions for damages. This is set out in line with the 'any individual' formulation of the CJEU in Courage ${ }^{54}$; it covers all natural and legal persons that have suffered harm due to infringement of European or national competition law.

According to the express wording of Art 12 DADA, this also includes indirect victims, i.e. it takes account of the interplay between direct and indirect purchasers. If a cartel overcharges for goods, it is often not only those who purchase directly from the infringer who are affected. In many cases, goods are sold on down a chain, sometimes after further processing. If the direct purchaser can in turn pass on the anti-competitive price to those who purchase from him, these indirect purchasers also suffer pecuniary damage. The question of the standing of such indirect purchasers was largely controversial in the Member States up until now; for instance, the German Federal Court of Justice only affirmed such a right to standing following the decision ORWI in 2011..$^{55}$

As shown above, the question of standing for indirect purchasers is closely linked with the damage suffered by the direct purchaser, i.e. the intermediary trader. In the first instance, this means merely that the indirect purchaser only suffers damage if the purchaser further up the chain passes on the anti-competitive price to his own customers, i.e. the indirect purchasers. However, if the claimant can pass his loss on to the next level in the market, he has not actually suffered damage to this full extent. In this context, Germanic lawyers speak of 'Vorteilsausgleichung' (roughly translating as 'off-setting the advantage gained'), in the general context here it is taken into account in the passing-on defence. ${ }^{56}$

In Art 13, the DADA provides for just such a passing-on defence; the defendant infringer can invoke the defence that the interim trader bringing the action passed on all or part of the overcharge. The burden of proof in this respect is on the defendant; as such he can accordingly require disclosure by the claimant or third parties.

\footnotetext{
53 Recital 11 DADA; Kersting, WuW 2014, 564 (565); Makatsch/Mir, EuZW 2015, 7; cf also Vollrath, NZKart 2013, 434 (438) on the nexus between being subject to proceedings imposing fines and actions for damages, doubtful with respect to the need for amendments in German law Stauber/Schaper, Die Kartellschadensersatzrichtlinie-Handlungsbedarf für den deutschen Gesetzgeber?, NZKart 2014, 346 (347).

54 CJEU 20.9.2001-C-453/99, Courage/Crehan, ECLI:EU:C:2001:465, no 26.

55 BGH 28.06.2011-KZR 75/10, ORWI, BGHZ 190, 145, no $20 \mathrm{f}=$ BeckRS 2011, $26581=$ BB 2012, $75=$ EuZW 2012, $103=$ GRUR 2012, 291 (Comm Ackermann, Franck) = GRUR-Prax 2011, 543 $($ Comm Seitz $)=$ GWR 2012, $10($ Comm Hooghoff $)=$ JuS 2012, $847($ Comm Emmerich $)=$ JZ 2012, $789=$ NJW 2012, $103=$ WRP 2012, $209=$ WuW 2012, $57=$ ZIP 2012, 390.

${ }^{56} \mathrm{Cf}$ in detail and with further references Polster/Steiner, ÖZK 2014, 43 as well as BGH 28.06.2011KZR 75/10, ORWI, BGHZ 190, 145; Court of Appeal [2008] EWCA Civ 1086, no 109, 114, 147, 151Devenish Nutrition v. Sanofi-Aventis SA (France and others); High Court of Justice (Chancery division) [2009] EWHC 741 (Ch), no 36-Emerald Supplies v. British Airways.
} 
Besides this, under Art 12 para 5 DADA, the courts deciding the case are entitled to estimate the share of the overcharge passed on. The purpose of the rule is quite clear-intermediate traders who bring such claims must not be over-compensated (Art 12 para 2 DADA) - but, in my view, this construction certainly runs the risk of being too generous to the defendant. On the one hand, the defendant does not in fact have to provide complete proof, since the court may estimate the overcharge, whilst on the other, the option of requiring disclosure from the claimant means the defendant could delay the proceedings and obtain internal data from the claimant, and thus build up a certain level of intimidation with the aim of forcing a settlement. Any follow-on actions claims are likely to be little served by this rule.

\subsection{Harm}

In line with the CJEU decisions Courage and Manfredi, ${ }^{57}$ it ought to be possible to seek full compensation. Sedes materiae is Art 3 para 1 DADA whereby '....any natural or legal person who has suffered harm caused by an infringement of competition law is able to claim and to obtain full compensation for that harm ....'. Such full compensation also includes the compensation of lost profits (lucrum cessans), plus interest from the point at which the harm was sustained; ${ }^{58}$ this will make for significant sums, especially when it comes to long-running cartels. ${ }^{59}$

Actually quantifying the damage suffered from competition law infringements is one of the most difficult obstacles to actions for damages, so much so that the European legislator also supplies recommendations on such procedures. In the light of Recitals 45 and 46 DADA, the starting point must be that the quantification of anti-trust damage is very complicated with respect to establishing and evaluating the facts, and necessitates the use of complex economic models; moreover, obtaining data and carrying out the calculations is expensive and specialists are essential. The Commission's 'Practical Guide' is therefore intended to simplify the quantification of harm caused by cartels, and, in particular, to guarantee uniform procedure across the Member States when it comes to assessing the harm. ${ }^{60}$ Furthermore, the DADA states that the national competition authorities can assist the courts with quantifying the harm. ${ }^{61}$ The Impact Assessment Report showed ${ }^{62}$ that in about $95 \%$ of the cartels analysed there were definitely overcharges; accordingly, the DADA takes a decisive further step: under Art 17 para 2 DADA, there is a rebuttable presumption that cartel infringements cause harm.

\footnotetext{
57 CJEU 20.9.2001-C-453/99, Courage/Crehan, ECLI:EU:C:2001:465; CJEU 13.7.2006-C-295-298/ 04, Manfredi, ECLI:EU:C:2006:461.

58 Art 3 (2), Art 12 (3) Directive; CJEU 13.7.2006-C-295-298/04, Manfredi, ECLI:EU:C:2006:461, no 97.

59 Koch/Thiede, ETL 2014 (2015) no 5.

60 Commission, Practical Guide on quantifying harm in actions for damages based on breaches of Article 101 or 102 of the Treaty on the Functioning of the European Union, SWD(2013) 205.

61 Art 17 (3) DADA.

62 Commission, Impact Assessment Report SWD(2013) 204 final.
} 
As might be expected, this presumption is the subject of vehement debate in Austria, ${ }^{63}$ because tort law concepts there are rooted in the incidence of damage, which the claimant always has to prove. From an Austrian perspective, therefore, any presumption of damage constitutes a quite substantial interference in national tort law. When a European rule has such a great impact on one national tort law, it is often useful to review the exact reservations advocated there. One major argument in the Austrian literature, that a quota cartel does not necessarily result in harm to the other market participants, ${ }^{64}$ may sound quite persuasive. However, when such conduct is seen in the light of Community law (as it must be), ${ }^{65}$ it becomes evident that a quota cartel is nothing more than a production cartel-and, hence, the argument raised must be disregarded. On the other hand, we have to concede that proving damage always represents a substantial enough problem in any action for damages exceeding a certain level of complexity, and mostly requires an economic understanding of the facts. To that extent, the fears being nursed might be wellfounded, and the presumption of harm in the DADA could serve as a negative example for future legal unification projects by the European legislator. In any case, though, it is to be expected that numerous Member States will implement the presumption of damage extremely narrowly and explicitly limit it to cartels. ${ }^{66}$

Even where damage is presumed-alleviating an obstacle to successful actionsat the end of the day the judge will have to put a figure on it. This remaining hurdle is eased by Art 17 para 1 DADA, according to which the Member States must ensure that quantification of the extent of the damage does not render it practically impossible for the victim to exercise his right to compensation. Hence, domestic courts ultimately should have the right to estimate the amount of damage when it has been proven that a claimant suffered harm but it is excessively difficult to quantify its extent on the basis of the available evidence.

\subsection{Disclosure of evidence}

The potentially high damage awards give the claimant a clear incentive to file an action. Obviously the risk of litigation must be considered; we note that in this type of cases a double-digit number of joint defendants, and consequently considerable costs, ${ }^{67}$ must be anticipated. The excessive volume of litigation rests very decisively on the available evidence for anti-competitive conduct. This evidence is, however,

\footnotetext{
${ }^{63}$ Rittenauer/Brückner, wbl 2014, 303 (309).

64 Rittenauer/Brückner, wbl 2014, 303 (309).

65 CJEU 16.5.2013-C-228/11, Melzer/MF Global UK Ltd, ECLI:EU:C:2013:305, no 32-35; CJEU 21.6.1978-150/77, Bertrand, ECLI:EU:1978:1431, no 14-16; CJEU 17.06.1992—C-26/91, Handte, ECLI:EU:C:1992:268, no 19; CJEU 19.1.1983-C-89/91, Shearson Lehman Hutton, ECLI:EU:C:1993:15, no 13; CJEU 3.7.1997-C-269/95, Benincasa, ECLI:EU:C:1997:337, no 12; CJEU 27.4.1999-C-99/96, Mietz, ECLI:EU:C:1999:202, no 26; CJEU 11.6.2002, C-96/00, Gabriel, ECLI:EU:C:2002:436.

66 Rittenauer/Brückner, wbl 2014, 303 (309).

67 Buntscheck, "Private Enforcement" in Deutschland: Einen Schritt vor und zwei Schritte zurück, WuW 2013, 947 (955); Makatsch/Mir, EuZW 2015, 7 (8); Mederer, EuZW 2013, 847 (848); Weitbrecht, NJW 2012, $881(883)$.
} 
hard to come by: ${ }^{68}$ neither press releases from the European or national competition authorities, nor public reporting contain information that will stand up in court. The information provided by the national authorities is currently limited: arguably claimants only get access to the index of files and anonymised decisions on the fines imposed, in each case with information that can hardly be used. ${ }^{69}$ Understandably, potential claimants abstain from making claims in this situation.

However, the proof is out there, which is why the European legislator aims to compel access to evidence of the infringement in the hands of the defendants, third parties or competition authorities ${ }^{70}$ : Art 5 and 6 DADA provide that domestic courts are entitled to order disclosure by competition authorities, the defendant, and third parties of specific evidence and relevant categories of evidence (Art 5 para 2, Art 6 para 9 DADA), and can penalise failure to do so (Art 8 DADA).

In order to avoid any actions to discover internal information on (potential) claimants or competitors, there must be a substantiated, reasoned application for the disclosure which plausibly supports the claim for damages. ${ }^{71}$ For the same reason, under Art 5 para 3 DADA the court must, in addition to examining whether the disclosure is necessary, weigh up whether it is proportionate given the likelihood of infringement, the extent and costs of the disclosure, and how confidential the relevant information is. According to Art 5 para 4 s 2 DADA, confidential information must be protected, and under Art 5 para 7 DADA parties affected must be heard before the disclosure. Art 6 DADA adds specific provisions on court disclosure of evidence from competition authority files to these general considerations on disclosure of evidence.

A problem associated with leniency programs ${ }^{72}$ which has also been at issue before the CJEU must be considered too: Austrian competition authorities hadwith reference to such programs for whistle-blowers and the corresponding rule in $\S$ 39 (2) of the Austrian Cartel Act (Kartellgesetz), which makes access to the court files contingent upon the "consent of the competition law rules infringer" ${ }^{73}$-refused to make relevant evidence accessible. The CJEU held in this respect that in the absence of binding regulation under European Union law ${ }^{74}$ it is up to the domestic courts, 'on the basis of their national law, to determine the conditions under which such access must be permitted or refused by weighing the interests protected by

\footnotetext{
${ }^{68}$ Recitals 14 and 45 DADA.

69 Makatsch/Mir, EuZW 2015, 7 (8).

${ }^{70} \mathrm{Cf}$ on this in particular CJEU 14.6.2011-C-360/09, Pfleiderer, ECLI:EU:C:2011:389, no 23; CJEU 6.6.2013-C-536/11, Donau Chemie, ECLI:EU:C:2013:366, no 25.

71 All evidence or categories of evidence must be determined as precisely as possible. The claimant must present the facts and evidence accessible with reasonable efforts which deliver plausible grounds for suspecting an infringement of competition law, as well as the existence of damage and a causal link between the infringement and the damage. If the evidence is in the sphere of a third party or the defendants, the relevance of such to substantiating the claimant's claim must be proven. Makatsch/Mir, EuZW 2015, 7 (9); Mederer, EuZW 2013, 847 (849); Koch/Thiede, ETL 2014, no 8.

72 See no 8, supra.

73 In detail on the facts: AG Jääskinen-C-536/11, Donau Chemie, ECLI:EU:C:2013:67, no 51.

74 CJEU 14.6.2011-C-360/09, Pfleiderer, ECLI:EU:C:2011:389, no 23; cf also ECJCJEU 6.6.2013C-536/11, Donau Chemie, ECLI:EU:C:2013:366, no 25.
} 
European Union law'. ${ }^{75}$ Moreover, the CJEU concluded with respect to considerations regarding the protection of leniency programs that 'they do not necessarily mean that that access may be systematically refused' and formulated case-by-case ${ }^{76}$ standards for assessment. ${ }^{77}$

As we have seen, public prosecution of anti-competitive conduct largely depends on whistle blowing. It is vital which documents must be protected on a permanent or temporary basis by the national and European competition authorities. Necessarily, this puts a focus on how the treatment of whistle-blowers and their testimony is regulated; the crucial voluntary cooperation of undertakings with the competition authorities in order to expose cartels, which otherwise would become less likely for fear of possible later disclosure, is of course undisputed. Accordingly, Art 6 para 6 DADA prohibits the court disclosure of "leniency statements ${ }^{, 78}$ and 'settlement submissions' ${ }^{79}$ However, the relevant national court confronted with this issue must ensure, upon reasoned application by the claimant, that actual leniency statements and settlement submissions are really at issue, as described in detail by the definitions of these terms in Art 2 para 16 and para 18 DADA; the corresponding contents of the document cannot be passed on and the authors must also be given the opportunity to be heard. The rule in Art 6 para 5 DADA furthermore protects proceedings before competition authorities, providing that the courts may only order the disclosure of certain information after such proceedings have concluded; this includes information that was put together for the competition authority's proceeding, and by the competition authority and communicated to the parties, ${ }^{80}$ as well as settlement submissions that have been withdrawn. In comparison to the provisions of Art 5 and Art 6 para 4 DADA, this sets higher proportionality standards in relation to the disclosure of competition authority evidence; the claimant's application must be sufficiently specific and the court must also take into account 'the need to safeguard the effectiveness of the public enforcement of competition law.' Further, it must be the case that no party or third party can reasonably provide the information. ${ }^{81}$ Art 7 DADA sets out restrictions for evidence that is obtained by access to the files of a competition authority; these are identical

\footnotetext{
$\overline{75}$ CJEU 14.6.2011-C-360/09, Pfleiderer, ECLI:EU:C:2011:389, no 32.

76 Kersting, Anmerkung zu C-536/11, JZ 2013, 737 (739); Hempel, Einsicht in Kartellverfahrensakten nach der Transparenzverordnung-Neues aus Luxemburg, EuZW 2014, 29.

77 CJEU 6.6.2013-C-536/11, Donau Chemie, ECLI:EU:C:2013:366, no 43.

78 'Leniency statement' means an oral or written presentation voluntarily provided by, or on behalf of, an undertaking or a natural person to a competition authority or a record thereof, describing the knowledge of that undertaking or natural person of a cartel and describing its role therein, which presentation was drawn up specifically for submission to the competition authority with a view to obtaining immunity or a reduction of fines under a leniency programme, not including pre-existing information, Art 2 (16) Directive.

79 'Settlement submission' means a voluntary presentation by, or on behalf of, an undertaking to a competition authority describing the undertaking's acknowledgement of, or its renunciation to dispute, its participation in an infringement of competition law and its responsibility for that infringement of competition law, which was drawn up specifically to enable the competition authority to apply a simplified or expedited procedure, Art 2 (18) Directive.

${ }^{80}$ Cf Recital 25 DADA.

81 Art 6 (10) DADA.
} 
to those in Art 6 DADA, in order to block any attempts to circumvent that provision. In order to make sure that it is not possible to trade with the evidence, Art 7 para 3 DADA also restricts the right to use evidence only obtained by access to the files to the person that had access or the person that has succeeded to this person's rights or has acquired such a person's claim. ${ }^{82}$

The possible disclosure of evidence, in particular by competition authorities, must be considered when evaluating the volume of litigation. The rules discussed give claimants access to evidence, but at the same time try not to jeopardise public law enforcement. Whether this very fine balance has been successfully struck seems doubtful. Given the leeway provided for the domestic courts to balance the interests at hand, we will observe future court practice and see how and to what extent applications for disclosure are considered; ${ }^{83}$ numerous references to the CJEU for preliminary rulings seem inevitable. ${ }^{84}$ On the other hand, the rules set out in Art 6 para 5 and 6 DADA (no disclosure of leniency statements and settlement submissions) fall behind the existing disclosure possibilities in some Member States; in the Netherlands, in the UK and also in Germany there are means for further-reaching disclosure of competition authority documents. ${ }^{85}$ These more extensive means were created subsequent to the Pfleiderer Case, so that it is occasionally called into question whether the present rule in Art 6 para 6 DADA, with its unreserved exclusion of disclosure of leniency statements, is not in conflict with that CJEU decision. The CJEU after all held that a specific balancing between the interests of providing the information and the protection of the leniency statement must be conducted in each case individually. ${ }^{86}$ Predictably, some Member States object that Art 6 para 6 DADA conflicts with Art 101 TFEU; in the light of the (alleged) conflict of this ban on the disclosure of leniency statements and settlement submissions with primary law, there is even open support for an action for annulment before the CJEU under Art 263 TFEU. ${ }^{87}$ The outcome of these

\footnotetext{
82 All other documents must be disclosed, Art 6 (9) DADA.

83 Thus, apparently, Mederer, EuZW 2013, 847 (849).

84 According to the CJEU in C-536/11, Donau Chemie, ECLI:EU:C:2013:366, no 31; C-360/09, Pfleiderer, ECLI:EU:C:2011:389, no 34 ,on a case-by-case basis, [...], and taking into account all the relevant factors in the case' all interests protected by Union law must be taken into account and, in particular, there must be a weighing up of the right to damages and the protection of leniency programs.

${ }^{85}$ Cf for the Netherlands, for example, Art 843a Wetboek van Burgerlijke Rechtsvordering; for the UK High Court of Justice, National Grid v ABB \& Others [2012] EWHC 869 (Ch); part 31 Rules of Civil Procedure (CRP); Obersteiner, International antitrust litigation: How to manage multijurisdictional leniency applications, 4 (2013) ECLR 16 (25); for Germany BVerfG 6.3.2014-1 BvR 3541/13, NJW 2014, 1581; OLG Düsseldorf, 22.08.2012-V-4 Kart 5 + 6/11 (OWi), NZKart 2013, 39 no 44; OLG Hamm, 26.11.2013-1 VAs 116/13-120/13, 122/13, NZKart 2014, 107 no 36 ff; Bosch, Die Entwicklung des deutschen und europäischen Kartellrechts, NJW 2014, 1714; Harms/Petrasincu, Die Beiziehung von Ermittlungsakten im Kartellzivilprozess-Möglichkeit zur Umgehung des Schutzes von Kronzeugenanträgen?, NZKart 2014, 304; Lotze/Smolinski, Einsichtsrecht der Zivilgerichte in KartellAkten, EWiR 2014, 401; Schweitzer, Die neue Richtlinie für wettbewerbsrechtliche Schadensersatzklagen, NZKart 2014, 335 (342); Yomere/Kresken, Die Entscheidung des OLG Hamm zum Akteneinsichtsrecht von Zivilgerichten in Bonusanträge und vertrauliche Kommissionsentscheidungen, WuW 2014, 485 (489).

86 CJEU 14.6.2011-C-360/09, Pfleiderer, ECLI:EU:C:2011:389, no 30.

${ }^{87}$ Makatsch/Mir, EuZW 2015, 7 (10).
} 
efforts is uncertain; as long as Art 6 para 6 DADA has not been declared void, the Member States must implement the Directive's provisions. In the longer term, however, a greater tendency might reveal itself; claimants will get increased access to important evidence, which will certainly increasingly affect documents held by competition authorities.

From a practical perspective, various other aspects must still be examined. Under Art 5 para $1 \mathrm{~S} 2$ DADA, the defendant undertakings can also require the disclosure of evidence held by the claimant. Given numerous joint plaintiffs, this may very well lead to a veritable flood of applications; thus, the proceedings must be prepared very carefully in advance by the claimant with regard to the possible passing-on defences, ${ }^{88}$ as related applications for disclosure by the defendants must be anticipated right at the start of the proceedings.

In any case, the claimant's application for disclosure necessarily involves high costs, given the catch 22 situation that the claim for damages must be substantiated in order for the application for disclosure to be made without, logically enough, actually knowing the requisite information in advance, as it can only be obtained in the first place by the disclosure in question. The option allowed by Art 5 para 2 Directive will be helpful here, i.e. to apply for the disclosure of 'relevant categories of evidence', which in turn must be precisely circumscribed; in the words of the provision 'as precisely and as narrowly as possible on the basis of reasonably available facts in the reasoned justification'. How these criteria will be handled in practice will depend on the skill of the practitioners involved. Here too, many an application for a preliminary ruling can be expected.

The rule in Art 7 para 2 and 3 DADA will influence the behaviour of the parties in litigation, because in general claimants usually demand evidence for their proceedings against the other cartel participants within the context of settlements. Since Art 7 DADA provides that evidence may only be used by the person who obtained it by access to the files, or their legal successor, victims may no longer be able to use the information obtained in the process of settlements which the cartel participants obtain for disclosure through access to competition authority files. ${ }^{89}$

Finally, practitioners who take into account the international perspective in cases of cross-border cartels will have ample opportunity to improve the position of their clients: under Art 5 para 8 DADA, the Member States may maintain rules or introduce rules that would lead to a more comprehensive disclosure of evidence. As already explained, ${ }^{90}$ some Member States already have such further-reaching disclosure and other ways of collecting evidence, so practitioners in cross-border constellations should carefully weigh up which courts' jurisdictions should be invoked when bringing claims, which conflicts of laws rules are applied by these courts, and (finally) which Member States' substantive laws involve furtherreaching opportunities for disclosure. ${ }^{91}$

\footnotetext{
${ }^{88}$ No 17, supra.

89 Makatsch/Mir, EuZW 2015, 7 (10).

90 Cf no 28, supra.

91 Cf no 48, infra.
} 


\subsection{Binding effect of the decisions of competition authorities}

Before criticising the Directive due to the continued existence of obstacles to successful damages actions, two other aspects should be considered. With respect to the protection against disclosure of documents held by the authorities, it must be taken into account that such authorities not only collect such evidence but also render decisions as a result. If these decisions by the competition authorities are binding in any follow-on claim, then a much more promising picture emerges for the claimant; such a binding effect has thus far been provided for (as far as is apparent) in respect of the decisions of the European Commission, as well as those of some Member States, for instance in Germany ${ }^{92}$ and Austria. ${ }^{93}$

Now, if a national competition authority has established an infringement of competition law and rendered a final decision, then under Art 9 para 1 DADA the national courts are bound by this decision. In respect of final decisions that have been handed down by national competition authorities in other Member States, Art 9 para 2 DADA provides that these can be submitted as at least prima facie evidence that there was an infringement of competition law.

Insofar as a final decision of a national or European competition authority ${ }^{94}$ exists, the volume of litigation must be evaluated anew. The defendant (and codefendants) will be prevented from having questions already dealt with in the proceedings before the competition authority opened up again and thus from drawing out the proceedings in any subsequent action for damages. The conceivable objection that this breaches the defendant's right to be heard is not tenable, because the defendant has already had the opportunity to fight the competition authority decision at all instances in that context. ${ }^{95}$ The main advantage from a claimant's perspective would also be that the decision's binding effect both takes over from the presumption of damage under Art 17 para 2 DADA and can settle the question of proportionality in the sense of Art $5 \mathrm{ff}$ DADA to the claimant's advantage.

\subsection{Limitation}

Cartels are often only exposed after a decade or even more. Claims arising at the time when the cartel started could thus conceivably already be barred before the claimant knows anything of the cartel or any resulting claims. Hence, the rules on limitation in Art 10 DADA are intended to ensure that claimants have enough time to bring any claims for damages.

The limitation period for compensation claims should be at least 5 years and should not begin to run before the infringement has ended. Moreover, Member

\footnotetext{
92 Cf Art 33 (4) GWB.

93 Cf $\S 37$ a Austrian Cartel Act.

94 Cf Art 16 Regulation (EC) Nr 1/2003 of the Council of 16 December 2002 on the implementation of the rules on competition laid down in Articles 81 and 82 of the Treaty, OJ 2003 L 001, 1.

95 Rittenauer/Brückner, wbl 2014, 306 (310).
} 
States must guarantee that the limitation period only begins to run when four cumulative conditions have been met: the victim knows or ought to know of the conduct constituting the infringement, that it has been deemed an infringement of the competition law of the European Union or of national competition law, of the fact that he or she has sustained damage as a result, and of the identity of the infringer that caused the damage. In order to ensure that follow-on claims can also be brought in good time after there has been a final decision by a competition authority, the DADA provides for the limitation period to be suspended or interrupted during the competition authority proceedings, and to remain so for 1 year after the competition authority decision has become final.

Claimants (and legal counsel) will naturally welcome the minimum 5 year limitation period; this will change the situation in many Member States, ${ }^{96}$ for instance in Germany ${ }^{97}$ and Austria, ${ }^{98}$ while some other Member States do already have a five ${ }^{99}$ or even 6 year ${ }^{100}$ period.

However, it would seem doubtful whether the rule in Art 10 para 2 DADA, which provides that any limitation period only starts to run when the victim knows or ought reasonably to have known, also excludes the maximum absolute limitation periods which apply regardless of whether there was knowledge in some Member States. ${ }^{101}$ In my opinion, the fairly unequivocal wording of Recital 6 DADA indicates otherwise, as it states the Member States should in fact have the option of maintaining or introducing generally applicable absolute limitation periods as long as the duration of them does not make exercise of the right to full compensation practically impossible or excessively difficult. Since the balance between the claimant's interest in private enforcement and the interest in peace under the law is expressed directly with reference to the Member State's rules on absolute limitation periods, ${ }^{102}$ we believe it is not likely that many Member States will depart from absolute limitation periods applicable regardless of whether there was knowledge insofar as they have such provisions in the first place. ${ }^{103}$

\footnotetext{
96 For the inherent methodological problems, see no 21, supra.

97 Cf $\S \S 195,199$ German Civil Code (BGB); Fiedler, BB 2013, 2179 (2184).

98 Cf $\S 1489$ Austrian Civil Code (ABGB).

99 For example in the Netherlands, cf Art 3:310 (1) Burgerlijk Wetboek; Faure/Hartlief, The Netherlands, in Koziol/Steininger (eds) European Tort Law 2004 (2005) 420 (422).

100 For example in the United Kingdom for proceedings, cf section 32 Limitation Act; for proceedings before the CAT, (no 28, supra) the limitation period has thus far only been 2 years, but should as a consequence of the reforms described above also be raised to 6 years, Morony/Jasper, England and Wales, in Mobley (ed) Private Antitrust Litigation (2015) 56.

101 Thus, for example, Makatsch/Mir, EuZW 2015, 7 (11), i.e. in the case of Germany more than 10 years; § 199 (3) No 1 BGB.

102 Cf the detailed, comparative law descriptions by Zimmermann/Kleinschmidt, Prescription: Framework and Problems Concercing Damages Claims, in Koziol/Steininger (eds) European Tort Law 2007(2008) 26 (55) no $47 \mathrm{ff}$.

103 With a different forecast for Germany, Makatsch/Mir, EuZW 2015, 7 (11).
} 


\subsection{Joint and several liability ${ }^{104}$}

Art 11 para 1 DADA establishes the principle of joint and several liability; it provides that undertakings which have infringed competition law by their collusive conduct are jointly and severally liable for the damage caused. Each of the undertakings concerned can be obliged to compensate the entire damage, but can in turn seek contributions from the other infringers in proportion to their relative responsibility. ${ }^{105}$

The concept of joint and several liability is well-founded from a theoretical point of view. Rules with the same function can be found in several Member States ${ }^{106}$ and in more recent academic work on European private law. For instance, Art VI-4:102 of the Draft Common Frame of Reference (DCFR) provides that "[a] person who participates with, instigates or materially assists another in causing legally relevant damage is to be regarded as causing that damage', and consequently such participants are liable under Art VI-6:105 DCFR solidarily. The Principles of European Tort Law (PETL), drawn up by prestigious academics in the field,though not aimed at representing restatements of European law ${ }^{107}$ _also provide in Art 9:101 (1) (a) PETL that 'liability is solidary where the whole or a distinct part of the damage suffered by the victim is attributable to two or more persons. Liability is solidary where a person knowingly participates in or instigates or encourages wrongdoing by others which causes damage to the victim'. Obviously European

\footnotetext{
104 Art 19 DADA and the effect of consensual settlements on the solidary liability of the cartel participants will not be discussed here; according to Art 19 (1) DADA, the claim of the settling injured party is reduced by the settling co-infringer's share of the harm. The remaining claim may in principle only be asserted against the cartel participants that did not settle, who in turn may not recover against the infringer that settled (Art 19 (2) S 2 DADA). While Art 19 (3) provides that the settling victim can claim the remaining part from the settling infringer should the non-settling infringers not be able to pay, this can be expressly excluded in the consensual settlement. From a practical perspective, it must be noted that Art 19 of the Directive probably makes settlements more attractive with the rule that settling infringers are freed from recourse claims by other infringers. In this manner, the settling infringer's secondary duty to compensate can even be excluded when the remaining compensation cannot be obtained by the non-settling infringers. This also means that in future there will be more disputes regarding shares of liability, Krüger, Die haftungsrechtliche Privilegierung des Kronzeugen im Außenund Innenverhältnis gemäß dem Richtlinienvorschlag der Kommission, NZKart 2013, 483 (487).

105 Thus, if an undertaking pays more than its (relative) share for the damage caused to the claimant, it can in turn take recourse against the co-infringers, and in this respect the amount of this compensation should be determinable in their internal relationship according to national law; Recital 37 Directive sets out a number of criteria relevant for deciding the amount of the relative shares (such as turnover, market share and role within the cartel). This rule is basically in line with existing principles of solidary liability, cf for example the Austrian position OGH 5 Ob 39/11p=EvB1 2012,557= ecolex 2012, 392 $($ Wilhelm $)=\mathrm{RdW} 2012,523=\mathrm{WuW}$ 2012, 1251/KRInt 2012, $393=$ ZVR 2013, 76; Koutsoukou/ Pavlova, Der Gerichtsstand der Streitgenossenschaft bei Schadensersatzklagen wegen Verletzung des EU-Kartellrechts, WuW 2014, 153; Kriechbaumer/Bamberger, Private Enforcement-Die Rechtslage in Österreich, WuW 2014, 690.

106 See von Bar/Clive, Study Group on a European Civil Code/Research Croup on EC Private Law (Acquis Group), Principles, Definitions and Model Rules of European Private Law, Draft Common Frame of Reference (DCFR) (2009) Art VI-4:102, no 1-13 with extensive further reference.

107 Spier, General Introduction in: European Group on Tort Law, Principles of European Tort Law (2005) no 31.
} 
consensus tends towards joint and several liability for intentional joint conduct as well as the internal recourse. ${ }^{108}$

We cannot see why this should not apply here. All the more surprising, therefore, is the rule adopted by the European legislator to protect whistle-blowers in the context of solidary liability. According to Art 11 para 4 and para 5 S 2 DADA, infringers granted immunity from fines under a leniency program will only be solidarily liable within certain limits; in general they are only liable to their own (direct and indirect) purchasers and suppliers, unless it is impossible to obtain full compensation from other cartel participants. A similar limitation is also in place when it comes to other cartel participants' recourse claims against the whistle-blowers; the amount of their contribution toward the compensation may not be higher than the damage which they have caused to their own direct and indirect purchasers or suppliers.

This privilege would seem - as far as it seems with the exceptions of Hungary ${ }^{109}$ and Malta ${ }^{110}$-absent in all European Member States. Very rightly so, as it is particularly in cases of joint and several liability that privileges applicable outside of the internal relationship between those jointly liable are avoided. This is mostly in order to shield the victim from the risk and burden of having to assess the financial capacities of the individual injuring parties. ${ }^{111}$ This would be exactly the case here too: it remains unclear how it would be established that the victim "cannot obtain full compensation'. Is it sufficient that the other cartel participants refuse to pay? Must they already be insolvent? Or does a failed execution attempt suffice?

Certainly, undertakings infringing European or national competition law will drag out public prosecution as far as possible, whereas whistle-blowers will not (as the latter will rarely contest the administration's decisions). Thus, the decision against the whistle-blower will be the first to become final. Being the first then means greater exposure to follow-on damages claims. Nevertheless, this privilege for whistle-blowers seems excessive, not least because the solution to the underlying problem is obvious-whistle blowers should be privileged in their relationship internally to the cartel members but jointly and severally liable in full outside of this relationship, as is the case in so many Member States. ${ }^{112}$ This privilege within the relationship to the co-infringers when it comes to solidary liability is absolutely sufficient as protection. ${ }^{113}$

\footnotetext{
108 Neethling, Toward a European ius comune in tort law, 2006 Fundamina 12-1, 81 (88); Thiede/ Sommer, Vorsätzliche Schädigung von Anlegern im europaweiten arbeitsteiligen Wertpapiervertrieb, ÖBA 2015, 175 (184).

109 And even this appears uncertain in the light of the latest reform of Hungarian liability law, cf Menyhárd, Hungary, in Karner/Steininger (eds) European Tort Law 2013 (2014) 305 (311), no 8.

110 See Art 81(3) Police Act as changed by Act IV of 2014: The Various Law (Criminal Matters) (Amendment) Act 2014 (An Act further to Amend Various Laws related to Criminal Matters): 'In any civil proceedings instituted against a protected witness based on the fact that the said witness was the perpetrator or was an accomplice in the crime on which he tendered evidence, the court shall, if it finds that the protected witness is responsible for the payment of damages, only hold him liable for such part of the damage as he may have caused and shall, ..., hold him not liable jointly and severally with others.' Cf Caruana Demajo/Quintano/Zammit, ETL 2014, no 1.

111 Cf Krüger, NZKart 2013, 483 (486).

112 See the references in no 41.

113 Koch/Thiede, ETL 2014, no 9.
} 
It is particularly unsatisfactory that the European legislator also privileges another group of infringers besides the whistle-blowers, namely small and mediumsized enterprises (SMEs); after all, these constitute 99\% of European undertakings. ${ }^{114}$ SMEs are liable, under Art 11 para 2 DADA, only to their own purchasers if at the time of the infringement they had less than $5 \%$ market share, full liability would endanger their economic viability, and their assets would lose all of their value. Under Art 11 para 3 DADA, this does not apply if the SMEs at issue organised the infringement or coerced other undertakings to participate, or have previously been found to have infringed competition law. In respect of this special protection, the above explanations can be referred to cum grano salis; ${ }^{15}$ the questions of when economic viability can be deemed jeopardised and how assets could 'lose all their value' naturally arise. ${ }^{116}$

In summary, it may be noted that the privilege accorded to whistle-blowers and the derogation in favour of SMEs unnecessarily complicate the question of joint and several liability, which gives rise to more leverage for the defendants in the proceedings. $^{117}$

\section{International dimensions}

All of the above makes it clear that in arguably decisive matters (presumption of damage no 21; evidence no 28, limitation no 38; joint and several liability no 40), Member States will implement the DADA differently due to the nature of a European Directive. Indeed, some Member States have already gone further than the standards set out in the Directive; these standards will apply (prospectively) even after the transposition of the Directive in the Member State's laws. 118

Those practitioners who take into consideration the international dimensions of anti-trust damages actions thus have great opportunities in the case of cross-border cartels to substantially improve the position of their clients by carefully considering which courts to bring the action in-and which national law will be applied to decide the matter on the merits. ${ }^{119}$

\footnotetext{
114 Cf on the definition Commission, Recommendation concerning the definition of micro, small and medium-sized enterprises (2003/361/EC), OJ 2003 L 124, 36 ff as well as Commission, The new SME Definition (2005) 5 and finally Evaluation of the SME Definition (2012), online http://ec.europa.eu/ enterprise/policies/sme/files/studies/executive-summary-evaluation-sme-definition_en.pdf 4.

115 Cf no 41.

116 Kersting, WuW 2014, 564 (568).

117 For this reason, Germany, Poland and Slovenia have refused their consent to the Directive's compromise in the Council, cf Council Document 14680/14 ADD $1=2013 / 0185$ (COD).

118 Cf Art 4 S 2, Art 5 (8), Art 6 (9), Art 10 (4) Directive.

119 This is referred to as forum shopping, on the term see Lurger/Thiede, The International Dimensions of Law (2015) no 2/13.
} 


\subsection{International jurisdiction}

The first question confronting a potential claimant wishing to seek compensation from an undertaking which has infringed anti-trust law Europe-wide is the court in which Member State has adjudicary jurisdiction. ${ }^{120}$ Thus, the first factor is the international jurisdiction of the Member States.

The needs of the common European market have meant that the European legislator has been particularly active in the area of international jurisdiction. As early as 1968, the Brussels Convention on Jurisdiction and the Enforcements of Judgments in Civil and Commercial Matters was adopted by the Member States of the European Community and came into force in 1973. The Brussels Convention was subsequently amended by four accession conventions, and was finally replaced (for fourteen of the then fifteen EC Member States) by Regulation 44/2001 on Jurisdiction and the Recognition and Enforcements of Judgments in Civil and Commercial Matters adopted by the EC Council in December 2000. The 'recast' of the Regulation entered into force on 1 January 2015 (hereafter Brussels I Regulation). ${ }^{121}$ The Regulation, like the earlier Convention, lays down rules on direct jurisdiction applicable in the court of first instance to determine its own jurisdiction, and on the recognition and enforcement of judgments of other Member States of the European Union in which the Regulation applies. In the context of private enforcement with respect to anti-trust damages actions, international jurisdiction of the Member State courts is determined primarily by this Brussels I Regulation (recast). The regulation does not provide specifically for any cartelrelated rules, hence the general rules must be applied.

\subsubsection{General jurisdiction at place of defendant's domicile, Art 4 Brussels I Regulation}

The basic rule concerning direct jurisdiction is enshrined in Art 4 Brussels I Regulation, which provides that 'persons domiciled in a Member State shall, whatever their nationality, be sued in the courts of that Member state.' The Brussels I Regulation applies whenever the defendant is domiciled in a Member State, regardless of whether or not the claimant is situated in the European Union. ${ }^{122}$ For any

\footnotetext{
120 The link between implementation of the DADA and the applicable law may only arise indirectly from the choice-of-law rules in some constellations; namely under Art 3 para 4 Rome I Regulation; Art 14 para 2 Rome II Regulation; Art 14 para 3 Rome II Regulation, Directives must be applied in the form in which they have been implemented in the Member State whose court is seised.

121 Regulation (EU) No 1215/2012 of the European Parliament and of the Council of 12 December 2012 on jurisdiction and the recognition and enforcement of judgments in civil and commercial matters, OJ 2012 L 351, 1 ff.

122 The rationale for this long-standing rule in favour of the defendant's domicile was outlined clearly by the CJEU in Handte v TMCS, ECLI:EU:C:1992:268 noting that the rule reflects the purpose of strengthening the legal protection of persons established within a particular current national jurisdiction, and rests on the assumption that a defendant can usually best conduct his or her defence in the courts of his or her domicile. Another (likely) reason for favouring the defendant over the plaintiff is that the defendant's assets are most likely at his place of domicile and enforcement against persons or property can thus most easily be effected there. Thus, the rule tends to concentrate both adjudication of the merits
} 
undertakings, Art 4 Brussels I Regulation is extended by Art 63 Brussels I Regulation; accordingly courts are internationally competent to hear an action against a defendant undertaking at the place where the registered headquarters or main branch of the undertaking is situated.

For the following discussion of competent courts in (potentially) other Member States, we have to keep in mind that the all-important paradigm then deviated from is set; when it comes to actions against undertakings which have infringed anti-trust law, it is basically the court of their domicile (viz. their headquarters or main branch) which has jurisdiction to examine the legal and economic aspects of claims for anti-trust damages, as well as related cartel-related agreements.

\subsubsection{Jurisdiction for contractual matters, Art 7 no 1 Brussels I Regulation}

An exaggerated preference for the defendant's domicile does not provide the most appropriate solutions in all situations, actions and claims in cross-border cases, as this mostly takes the defendant's interests into account. As it seems odd to subjugate the interests of the claimant to those of the defendant in general, the Brussels I Regulation provides for particular alternative jurisdictions if the defendant is to be sued in the courts of a state other than that of his or her domicile. According to the European legislator, this freedom of choice was introduced in the light of the existence, in certain well-defined cases, of a particularly close relationship between the dispute in question and the court where it might be most convenient to adjudge the matter.

The first exception to the rule on general jurisdiction above is of interest with regard to an undertaking which violates European or national competition law where specific contracts were agreed upon which stipulated for that violation of European or national competition law. According to Art 7 no 1 Brussels I Regulation, a 'person domiciled in a Member State may, in another Member State, be sued ... in matters relating to a contract, in the courts for the place of performance'. The courts at the place where anti-competitive contractual agreements were performed have jurisdiction when it comes to declaring anti-competitive contractual agreements null and void. With regard to the topic chosen here, antitrust damages under the DADA, we must note that potential claimants will not merely seek a declaration that a contractual agreement is null and void, but possibly also seek damages (as provided by the DADA) instead. This latter action for damages is arguably delictual in nature, ${ }^{123}$ and could thus, under Art 7 no 2 Brussels

\footnotetext{
Footnote 122 continued

and enforcement of the judgment in the same country, thereby avoiding unnecessary procedural complications (which were of course also relieved to great extent by the Brussels I Regulation recast).

123 See CJEU 16.5.2013-C-228/11, Melzer/MF Global UK Ltd, ECLI:EU:C:2013:305, no 32-35; CJEU21.6.1978-150/77, Bertrand, ECLI:EU:C:1978:1431, no 14-16; CJEU 17.6.1992-C-26/91, Handte, ECLI:EU:C:1992:268, no 19; CJEU 19.1.1983-C-89/91, Shearson Lehman Hutton, ECLI:EU:C:1993:15, no 13; CJEU 3.7.1997-C-269/95, Benincasa, ECLI:EU:C:1997:337, no 12; CJEU 27.4.1999—C-99/96, Mietz, ECLI:EU:C:1999:202, no 26; CJEU 11.6.2002, C-96/00, Gabriel, ECLI:EU:C:2002:436.
} 
I Regulation, open up the possibility of courts in the places where 'the harmful event occurred' having jurisdiction, that is jurisdiction in tort. ${ }^{124}$

A fascinating follow-up problem ${ }^{125}$ on the relation between both rules arises here. Firstly, one may argue that the place of jurisdiction in relation to delict also decides on contractual, i.e. non-delictual, claims. The CJEU clearly rejected such annex-jurisdiction with reference to the restrictive interpretation of special jurisdiction in $1988 .^{126}$ Vice versa, the delict claims in relation to anti-trust violations could also be decided at the place of jurisdiction for contract. ${ }^{127}$ The latter constellation was submitted to the CJEU only recently, in the Brogsitter Case $^{128}$; the Luxembourg judges decided that a claim does not fall outside of Art 7 no 1 Brussels I Regulation just because it is raised on the basis of civil law liability against the other contractual party, but certainly it does "where the conduct complained of may be considered a breach of contract, which may be established by taking into account the purpose of the contract'. ${ }^{129}$ This would be the case in principle, according to the judges, "where the interpretation of the contract which links the defendant to the applicant is indispensable to establish the lawful or, on the contrary, unlawful nature of the conduct complained of against the former by the latter'. ${ }^{130}$

From the perspective of the practitioner on the ground, the decision in the Brogsitter Case is questionable, as it could mean that the jurisdiction at the place of the delict under Art 7 no 2 Brussels I Regulation is impeded. ${ }^{131}$ If the claimant brings an action for damages, not at the place of jurisdiction for contractual matters under Art 7 no 1 Brussels I Regulation, but at the place(s) of jurisdiction for delictual matters under Art 7 no 2 Brussels I Regulation (the latter being a different jurisdiction), then the defendant will only need to claim in line with Brogsitter that his or her conduct was contractually justified, or that an interpretation of the contract is certainly necessary to judge on the case, and thus that the court in the place of jurisdiction for contractual matters also has international jurisdiction for delictual claims. In consequence, a number of actions will be rejected at the place of jurisdiction for delict due to the annex competence of the courts at the place of jurisdiction for contract.

\footnotetext{
124 See no A.Part I.I.A.1.a)i)59, infra.

125 See Dornis, Von Kalfelis zu Brogsitter-künftig enge Grenzen der Annexkompetenz im europäischen Vertrags- und Deliktsgerichtsstand, GPR 2014, 352 (353) with further references; Czernich in Czernich/ Kodek/Mayr, Europäisches Gerichtsstands- und Vollstreckungsrecht ${ }^{4}$ (2015) Art 7 EuGVVO no 19.

126 CJEU 27.9.2988 - C-189/87, Kalfelis, ECLI:EU:C:1988:459, NB contrary to the view of AG Darmon cf ECLI:EU:C:1988:312. Cf CJEU 11.10.2007, C-98/06, Freeport plc/Olle Arnoldsson, Slg 2007, I-8319.

127 In favour, for example Kropholler/von Hein, Art 5 EuGVVO no 79, cf on this Spickhoff, Anspruchskonkurrenzen, Internationale Zuständigkeit und Internationales Privatrecht, IPRax 2009, 128 ff; Engert/Groh, Internationaler Kapitalanlegerschutz vor dem Bundesgerichtshof, IPRax 2011, 466 with further references; with a different opinion Gottwald, Anmerkung, IPRax 1989, 272 (274).

128 ECJCJEU 13.3.2014-C-548/12, Brogsitter, ECLI:EU:C:2014:148.

129 CJEU13.3.2014-C-548/12, Brogsitter, ECLI:EU:C:2014:148, no $24 \mathrm{f}$.

130 CJEU 13.3.2014 C-548/12, Brogsitter, ECLI:EU:C:2014:148, no 25.

131 Mansel/Thorn/Wagner, Europäisches Kollisionsrecht 2014: Jahr des Umbruchs, IPRax 2015, 15.
} 


\subsubsection{Place of jurisdiction for delictual matters, Art 7 para 2 Brussels I Regulation}

The preference for the place of jurisdiction for contractual matters ultimately fits into a whole series of unfathomable CJEU decisions on special jurisdiction in relation to delictual matters; the system arising from these decisions is predominantly shaped by judge-made law and holds a host of uncertainties for the practitioner.

To start with, Art 7 no 2 Brussels I Regulation stipulates that in matters relating to torts, delicts or quasi-delicts, a person domiciled in a Member State may sue in another Member State 'in the court of the place where the harmful event occurred'. The application of this rule is unproblematic in cases where the harmful conduct, that is to say the action eventually leading to the damage, and its result, the damage, are located in the same country. However, the wording is unclear in cases where the place where the wrongful action took place and the place where the resulting damage arose are actually in two countries (delict over a distance). The CJEU held in the Bier Case ${ }^{132}$ that the provision must be understood as covering both the place where the damage occurred and the place where the event giving rise to the damage took place (ubiquity principle) and, as a rationale, referred to the equal proximity of both courts to the wrongful conduct or the infringement sustained.

As mentioned, these two places may, and quite frequently do, coincide, but the rule nevertheless poses problems in cases concerning international divisibility of damage; it was initially the Shevill Case ${ }^{133}$ that demonstrated the disadvantages of this ubiquity principle: following on logically from the Bier decision, the CJEU first had to confirm that in all those cases in which damage was sustained in numerous legal systems, the courts both at the place of conduct and in all places of the damage had international jurisdiction. ${ }^{134}$ The CJEU became aware of the possibility of forum shopping and, in response, introduced certain limitations on the choice of jurisdiction of the plaintiff; the court held that the tortfeasor could be sued at the place of his wrongful conduct, that is, at his or her domicile, for all harm caused, ${ }^{135}$ or before the courts of each Member State where damage was sustained by the victim. However, in the latter case, the courts of each Member State have jurisdiction solely in respect of the damage caused within their own territory. This technique was dubbed 'mosaic assessment' as it requires, where damage is sustained in several Member States, that the laws of all Member States concerned will have to

\footnotetext{
132 CJEU 30.11.1976-21/76, Bier, ECLI:EU:C:1976:166, no 24; Thiede, Internationale Persönlichkeitsrechtsverletzungen (2010) no 9/10 and recently, for example, CJEU 22.1.2015-C-441/13 Hejduk, ECLI:EU:C:2015:28, no 18.

133 CJEU 7.3.1995-C-68/93, Shevill, ECLI:EU:C:1995:61, no 32 = IPRax 1997, 111 (Comm Kreuzer) Klötgen 90) = Rev crit DIP 1996, 487 (Comm Lagarde $)=$ ZEuP 1996, $295($ Comm Huber $)=1$ ZZP Int (1996) 145 (Comm Rauscher).

134 In the Europe-wide cartels at issue here, therefore, this would also be courts in the Member States where the cartel had a concrete effect on the market.

135 With a different view Wurmnest, Internationale Zuständigkeit und anwendbares Recht bei grenzüberschreitenden Kartelldelikten, EuZW 2012, 933 (934) (limitation also of the courts at the place of conduct to the damage that occurred in that state).
} 
be applied on a distributive basis as tiny pieces, thus only together giving the complete picture of the mosaic of full compensation.

5.1.3.1 Place of conduct Given that courts at the place of the tortfeasor's conduct have full recognition to decide on the entire case, it is essential to determine which court is that at the place of conduct. In the Shevill Case, this jurisdiction had the distinct advantage that the defendant caused the Europe-wide damage only at one place of conduct, namely where it was registered. If this condition is fulfilled, the general definition of the place of conduct as the place at which the defendant caused the harmful event by its actions or omissions suffices. For instance, if an undertaking with a dominant position sells it goods under abusive conditions, and thus excludes third parties from the market, ${ }^{136}$ this undertaking undoubtedly acts in this one Member State and the courts of this one Member State have international jurisdiction for the action brought by the third party so excluded.

The question, however, is how to proceed when there is no one single place of conduct, for example when horizontal cartel agreements are at issue. If the place of conduct is understood as the place at which the forbidden cartel agreement was concluded, there would only be a clear, single place of conduct in cases where a cartel was concluded just one time, or at intervals but always in one particular place, such as at a fair that took place annually in the same city, for instance, and when the cartel participants then confirmed or modified the cartel during this fair every year. ${ }^{137}$ Even at first glance, it is obvious that this sort of 'organised cartel' ${ }^{138}$ would be rather rare, so we are left with the question of how to proceed when participants in cartels make their agreements over years in many different places around the world. In that case there is a multitude of places of conduct, and thus the risks of forum shopping, on the one hand, and undue restriction of claimant jurisdictions, on the other.

One may argue that the decision to implement the cartel agreement at the registered seat of the cartel participants should be centre-stage, and here again refer to the decision in Shevill; in this decision too, the place of conduct was undoubtedly the domicile of the defendant. ${ }^{139}$ This leads, however, to a situation where the special jurisdiction under Art 7 no 2 Brussels I Regulation becomes largely redundant; after all, the courts at the domicile of the defendant have international jurisdiction under Art 4 Brussels I Regulation anyway. ${ }^{140}$ Some accept this and

\footnotetext{
136 Cf, for example, the Case in OLG Hamburg, 19.4.2007-1 Kart U 5/06, GRUR-RR 2008, 31 (32); Mankowski, Der europäische Gerichtsstand des Tatortes aus Art 5 Nr 3 EuGVVO bei Schadenersatzklagen bei Kartelldelikten, WuW 2012, 797 (802).

137 Basedow, FS 50 Jahre FIW (2010), 129 (139).

138 Basedow, FS 50 Jahre FIW (2010), 129 (138) thus refers to these kinds of cases as "cartels with a solid organisation'.

139 Cf Mankowski, WuW 2012, 797 (802); Bulst, Internationale Zuständigkeit, anwendbares Recht und Schadensberechnung im Kartelldeliktsrecht, EWS 2004, 403 (405).

140 Cf F Bydlinski, Methodenlehre ${ }^{2}$ (1991) 444: translated here as 'If a certain interpretation results..., in (the) provision ... becoming devoid of purpose and function, then this interpretation shall not be applied.' In the specific context cf also Mankowski, WuW 2012, 797 (803); cf also Basedow, FS 50 Jahre FIW (2010), 129, $137 \mathrm{f}$.
} 
argue that it is almost impossible precisely to determine the place of the conduct in the case of horizontal cartel agreements, and that the place where the cartel was discussed must be irrelevant from a jurisdictional perspective. ${ }^{141}$ Finally, the Shevill Case is drawn upon with respect to the mosaic perspective on the place of the result, since this perspective would also apply when there is a multitude of places of conduct and it is argued that when a cartel is discussed and agreed in various different places, the power of the courts to decide on the case at these different places must be limited to that damage which arose in each state due to the specific agreement that was concluded there. ${ }^{142}$

The last restriction in particular is excessive. Should, for instance, it be clear where the cartel participants made their arrangements, the court with jurisdiction there should be competent in respect of the entire damage which arose. ${ }^{143}$ If no such single, unambiguous location can be determined, it will be necessary to admit thatat least for questions of international jurisdiction-there is not a sufficient link between unlawful conduct and place of jurisdiction.

5.1.3.2 Place of damage According to the interpretation of the CJEU, the socalled place of the damage is the place where the effects of the event triggering liability occur to the detriment of the victim. ${ }^{144}$ Since competition law rules serve the proper functioning of the market, ${ }^{145}$ logically the place of the damage must then be localised by reference to markets, specifically as the place where the defendant's infringement affected the market. ${ }^{146}$

\subsubsection{Jurisdiction in relation to connected claims, Art 8 para 1 Brussels I Regulation}

The above discussions clearly demonstrate that the complexity of the jurisdiction issue must not be underestimated in relation to Europe-wide cartels, for instance in the case of horizontal agreements. If there is a large number of defendants who participated in the cartel, it may be that full compensation can only be obtained if each participant undertaking is sued where it has its registered seat or where the relevant impact on the market occurred. The only practical way out of this

\footnotetext{
141 Cooper Tire \& Rubber Co. and others v. Shell Chemicals UK Ltd. and others [2009] EWHC 2609 (Comm) [65] (claimant is limited to the place of jurisdiction where the result occurred); in consequence also Bulst, EWS 2004, 403 (405) (place of conduct only where infringer has its seat).

142 Basedow, FS 50 Jahre FIW (2010), 129 (140).

143 With a different opinion Wurmnest, EuZW 2012, 933 (934) pointing to further, possible places of conduct.

144 CJEU 30.11.1976-21/76, Bier, ECLI:EU:C:1976:166, no 24; CJEU 16.7.2009—C-189/08, ZuidChemie, ECLI:EU:C:2009:475.

145 Bulst, EWS 2004, 403 (406); Mankowski, WuW 2012, 797 (804).

146 Mankowski, WuW 2012, 797 (805); with another opinion Mäsch, Vitamine für Kartellopfer: Forum shopping im europäischen Kartelldeliktsrecht, IPRax 2005, 509 (516) looking for the centre of financial interests. Cf also LG Dortmund 1.4.2004-13 O 55/02, EWS 2004, 434 (435) = BeckRS 2010, 02135. The latter view is, however, in clear contradiction to settled CJEU case law, cf only CJEU 10.6.2004-C168/02, Kronhofer, ECLI:EU:C:2004:364, no 19 f.
} 
dilemma is an action in one place of jurisdiction for closely connected claims under Art 8 no 1 Brussels I Regulation. This provision provides that several defendants can be sued together at the court of the state where one of them has his or her domicile, provided that the claims are so closely connected that it is expedient to hear and determine them together to avoid the risk of irreconcilable judgments resulting from separate proceedings. In other words, practitioners thus have the option of examining the respective national implementations of the DADA (no 49, supra) in the places of general and special jurisdiction where the members of the cartel are based in this respect and of bringing the action against one of the undertakings with its domicile in this legal system as the main defendant, and then to extend the action to all of the other infringers in the cartel under Art 8 no 1 Brussels I Regulation.

In favour of this approach, it may be said that one of the largest claimants of anti-trust damages within the context of the so-called bleach cartel, Cartel Damage Hydrogen Peroxide SA (CDC) ${ }^{147}$ took exactly this path; presumably in the light of the claimant-friendly German rules, ${ }^{148} \mathrm{CDC}$ sued six undertakings (which had already been prosecuted and fined by the European Commission) with registered seats in different Member States, ${ }^{149}$ and where only one of which was based in Germany (as the main defendant), jointly for damages before the German Regional Court (Landgericht) Dortmund, ${ }^{150}$ and invoked in this respect Art 8 no 1 Brussels 1 Regulation.

The subsequent actions taken by CDC seem truly astounding from a strategic, litigational perspective, and will be described here with the necessary brevity. After the claim was served on all defendants in the initial proceedings, but before the time had expired for the submission of answers to the claim and the beginning of the oral hearing, CDC dropped the proceedings against the German undertaking (as main defendant) on the basis of a settlement. The Regional Court of Dortmund $^{151}$ was thus confronted with the question of whether Art 8 no 1 Brussels I Regulation is also applicable when the main defendant is no longer being sued at its place of domicile by the claimant and referred this question to the CJEU. Although it was rather dubious in the light of the prior Melzer Case ${ }^{152}$-after all good arguments can be found for denying the competence of a court based on the association of claims when the main defendant is no longer part of the

\footnotetext{
$\overline{147} \mathrm{CDC}$ is a company with its registered seat in Belgium, which has as its object the assertion of actions for damages that are ceded to it by some of the undertakings harmed by the hydrogen-peroxide and sodium perborate cartel either directly or indirectly.

148 Cf no 5, supra.

149 The defendants were Akzo Nobel NV based in the Netherlands, Solvay SA based on Belgium, Kemira Oyj based in Finland, Arkema France SA based in France (CDC later withdrew the claim against this defendant), FMC Foret SA based in Spain and Evonik Degussa, which was the only one based in Germany (former defendant and now intervenor to support Akzo Nobel, Solvay, Kemira and Arkema France).

150 LG Dortmund, 29.4.2013-13 O (Kart) 23/09, EuZW 2013, $600=$ NZKart 2013, 472.

151 LG Dortmund, 29.4.2013-13 O (Kart) 23/09, EuZW 2013, $600=$ NZKart 2013, 472.

152 CJEU 16.5.2013-C-228/11, Melzer/MF Global UK Ltd, ECLI:EU:C:2013:305; cf on this with further references Thiede/Sommer, ÖBA 2015, 175 (184).
} 
proceedings ${ }^{153}$ - the CJEU accepted the German court as internationally competent to adjudicate on the matter. ${ }^{154}$

\subsection{Applicable law}

The next step in our international scenario relates to the applicable substantive private law. In order to determine which state's substantive law governs the dispute at hand, the competent court must determine which choice-of-law rule applies where an undertaking violates European or national competition law. Then, on that basis, the court must decide which State's private law to apply. In other words, after the court has selected the applicable choice-of-law rule and has made the choice between the 'competing' substantive Member State's laws it can proceed to determine the substantive outcome on the basis of the chosen law (and, of course, the evidence presented by the parties). ${ }^{155}$

With a view to the introductory cases above, it seems to be obvious that undertakings engaging in anti-competitive activities, in terms of economic size and impact, mostly operate on the whole European internal market. As a result, discussions on the choice-of-law rules nurse fears of a fragmentation of applicable law; just as in the realm of international jurisdiction, ${ }^{156}$ a 'mosaic assessment' seems possible. ${ }^{157}$ At first glance, Art 6 para 3 lit a Rome II Regulation ${ }^{158}$ seems to prove the point, as this regulation stipulates that the law applicable to noncontractual obligations arising out of a restriction of competition is the law of the country where the market is affected. The apprehension in practice is then constructed along the following lines: assuming that one Member State's court is competent to judge the full European violation of competition law, under art 6 para 3 lit a Rome II Regulation each law at the place(s) of anti-competitive actions must be applied. However, the latter law(s) only have relevance concerning the impact of that action on the markets of the Member State. Where damage is

\footnotetext{
153 Cf in detail Harms, Der Gerichtsstand des Sachzusammenhangs bei kartellrechtlichen Schadensersatzklagen, EuZW 2014, 129 (130 ff).

154 CJEU 21.5.2015-C-352/13, CDC v Akzo Nobel, ECLI:EU:C:2015:335.

155 Notwithstanding the explanations with respect to implementation of the Directive in no 49, skipping the test of choice-of-law allows the claimant to choose a court and thereby the substantive law of a specific jurisdiction which favours him or her as it, for example, awards significant damages or has a particularly advantageous system of evidence. In other words, the claimant may sway the substantive legal entitlements to his or her own advantage and, accordingly, to the disadvantage of his or her opponents. If this was permitted, the law would not serve a neutral and predictable mediatory function between the parties, and would in essence be unfairly biased against the defendant. The choice-of-law rules, at times referred to as 'meta-law' insofar as they are laws about law, prevent this kind of forum shopping by parties by rendering only one national legal system exclusively applicable to the case at hand, regardless of where the claim is litigated and which court is deemed internationally competent. By basing their decisions as to which law is applicable to cases with a foreign element on the same choice-oflaw rules, all European courts in whichever national jurisdiction are thus ultimately referring to the same substantive law.

156 See no A.Part I.I.A.1.a)i)59, supra.

157 Wurmnest, EuZW 2012, 933 (938).

158 Regulation (EC) No 864/2007 on the law applicable to non-contractual obligations, OJ 2007 L 199, 40 .
} 
sustained in several Member States, the laws of all Member States concerned will have to be applied on a distributive basis as tiny pieces which only reveal the full picture of the mosaic if seen together, ideally adding up to full compensation. As a result, the competent Member State's court would have to assess whether and to what extent harm occurred in the respective Member State, and how such harm can be indemnified there. Bearing in mind the differences in each jurisdiction-which need not disappear, as this is a minimum standard Directive-as well as divergent codification techniques, such a Herculean task should not be left to judges. Some raise doubts whether this standard of factual and legal accuracy could ever be met in practice. ${ }^{159}$ It is argued, as a practical alternative, that parties might bring their action solely in respect of the damage caused in the market of one Member State's territory. Of course, this way the aggrieved party will either fall short of full compensation or will have to pursue his or her claims in a number of courts throughout Europe, which would then clearly miss the goal set by art 3 DADA. ${ }^{160}$

The fears appearing in the discussions are mostly unfounded. While Art 6 para 3 lit a Rome II Regulation may initially raise alarm with regard to a mosaic assessment, Art 6 para 3 lit b Rome II Regulation provides a solution to be commended for those fields where a mosaic assessment is still in play. According to this provision, where the market is affected in more than one country, the person seeking compensation for damage (who sues in the court of the domicile of the defendant) may choose to base his or her claim on the law of the court seized, provided that the market in that Member State is amongst those directly and substantially affected by the restriction of competition out of which the noncontractual obligation on which the claim is based arises. In other words, where private parties sue for damage caused by a sizable European cartel, they may choose the law at the domicile of one of the cartelists as the law applicable to the anticompetitive action in the rest of the world.

\section{Summary}

The DADA will provide for change in several Member States; national liability laws will at least undergo amendment in the specific sub-areas discussed in this paper. The European legislator aspired, on the one hand, to avoid hindering successful public prosecution by the European and national competition authorities and, on the other, to create real incentives for private actions for damages against the infringers. The former aspect explains the somewhat odd rules with respect to whistle-blowers and leniency programs, the latter the extensive concessions towards potential claimants, for instance in the presumption of damage and the binding effect of decisions handed down by authorities. In particular, this binding effect of decisions by authorities facilitates follow-on claims to a hitherto unknown extent, so that all practitioners should be advised to keep track of the decisions rendered by

\footnotetext{
159 Koch/Thiede ETL 2014, no 8.

160 See no 19 , supra.
} 
competition authorities very carefully - and be ready to let corresponding follow-on claims succeed them.

In the case of such actions, the international dimensions must never be neglected. If a Europe-wide cartel is at issue, claimants have a range of options to improve their position if they take into account the different implementations of the Directive in the various Member States and choose a place of jurisdiction and applicable law accordingly. If a group of infringers are sued, the claimant should weigh up which Member State's law appears particularly favourable and bring the claim against the main defendant domiciled there.

Acknowledgements Open access funding provided by University of Graz. The author wishes to express sincere thanks to three fine colleagues, Fiona Saltor-Townshend, Bernhard A Koch and Andrew Bell for agreeing to undertake the at times tedious task of discussing and reviewing the original research, as well as earlier versions of this paper. Additionally, I would like to thank two anonymous reviewers for revealing crucial issues which needed to be addressed. Last but not least, my thanks go to Sonja Akbal for making the literature for the original research available. The author can be contacted at www. thomasthiede.info.

Open Access This article is distributed under the terms of the Creative Commons Attribution 4.0 International License (http://creativecommons.org/licenses/by/4.0/), which permits unrestricted use, distribution, and reproduction in any medium, provided you give appropriate credit to the original author(s) and the source, provide a link to the Creative Commons license, and indicate if changes were made.

\section{References}

Alexander C (2013) Wege und Irrwege - Europäisierung im Kartell- und Lauterbarkeitsrecht. Gewerblicher Rechtsschutz und Urheberrecht Internationaler Teil (GRUR Int) 2013:636 et seq.

Basedow J (2010) Der Handlungsort im internationalen Kartellrecht - Ein juristisches Chamäleon auf dem Weg vom Völkerrecht zum Internationalen Zivilprozessrecht. In: Festschrift 50 Jahre FIW. Cologne: Carl-Heymanns, pp 129 et seq.

Bosch W (2014) Die Entwicklung des deutschen und europäischen Kartellrechts. Neue Juristische Wochenschrift (NJW) 2014:1714 et seq.

Bulst WF (2004) Internationale Zuständigkeit, anwendbares Recht und Schadensberechnung im Kartelldeliktsrecht. Europäisches Wirtschafts- und Steuerrecht (EWS) 2004:403 et seq.

Bundeswettbewerbsbehörde (2014) Tätigkeitsbericht. Vienna

Buntscheck M (2013) "Private Enforcement" in Deutschland: Einen Schritt vor und zwei Schritte zurück. Wirtschaft und Wettbewerb (WuW) 2013:947 et seq.

Bydlinski F (1991) Juristische Methodenlehre, 2nd edn. Springer, Vienna

Cortese B (2012) Private Antitrust Enforcement - Status Quo in Italy. Europäische Zeitschrift für Wirtschaftsrecht (EuZW) 2012:730 et seq.

Czernich D (2015) Art 7 EuGVVO. In: Czernich/Kodek/Mayr (eds) Europäisches Gerichtsstands- und Vollstreckungsrecht, 4th edn. LexisNexis ARD ORAC, Vienna

Dornis TW (2014) Von Kalfelis zu Brogsitter - künftig enge Grenzen der Annexkompetenz im europäischen Vertrags- und Deliktsgerichtsstand. Zeitschrift für das Privatrecht der Europäischen Union (GPR) 2014:352 et seq.

Engert A, Groh G (2011) Internationaler Kapitalanlegerschutz vor dem Bundesgerichtshof, Praxis des Internationalen Privat- und Verfahrensrechts (IPRax) 2011:466 et seq.

European Commission (2003) Recommendation concerning the definition of micro, small and mediumsized enterprises (2003/361/EC), OJ 2003 L 124:36 et seq. 
European Commission (2005) Green Paper, Damages actions for breach of the EC antitrust rules, $\operatorname{COM}(2005) 672$ final

Faure M, Hartlief T (2005) The Netherlands. In: Koziol H, Steininger BC (eds) European tort law. Springer, Vienna

Fiedler L (2013) Der aktuelle Richtlinienvorschlag der Kommission - der große Wurf für den kartellrechtlichen Schadenersatz? Betriebsberater (BB) 2013:2179 et seq.

Fiedler L, Huttenlauch A (2013) Der Schutz von Kronzeugen- und Settlementerklärungen vor der Einsichtnahme durch Dritte nach dem Richtlinien-Vorschlag der Kommission. Neue Zeitschrift für Kartellrecht (NZKart) 2013:350 et seq.

Garzaniti L, Vanhulst O, Oeyen T (2012) Private Antitrust Enforcement - Status Quo in Belgium. Europäische Zeitschrift für Wirtschaftsrecht (EuZW) 2012:691

Harms R (2014) Der Gerichtsstand des Sachzusammenhangs bei kartellrechtlichen Schadensersatzklagen. Europäische Zeitschrift für Wirtschaftsrecht (EuZW) 2014:129 et seq.

Harms R, Petrasincu A (2014) Die Beiziehung von Ermittlungsakten im Kartellzivilprozess - Möglichkeit zur Umgehung des Schutzes von Kronzeugenanträgen? Neue Zeitschrift für Kartellrecht (NZKart) 2014:304 et seq.

Hempel R (2014) Einsicht in Kartellverfahrensakten nach der Transparenzverordnung - Neues aus Luxemburg. Europäische Zeitschrift für Wirtschaftsrecht (EuZW) 2014:29 et seq.

Howard A (2013) Too little, too late? The European Commission's Legislative Proposals on Anti-Trust Damages Actions, Journal of European Competition Law \& Practice (JECLaP) (2013) 4:455 et seq.

Kersting C (2014) Die neue Richtlinie zur privaten Rechtsdurchsetzung im Kartellrecht. Wirtschaft und Wettbewerb (WuW) 2014:564 et seq.

Koch BA, Thiede T (2014) European union. In: Karner E, Steininger BC (eds) European tort law (ETL). deGruyter, Berlin

Kofler-Senoner B, Siebert S (2012) Die private Durchsetzung von kartellrechtlichen Ansprüchen - Status Quo in Österreich. Europäische Zeitschrift für Wirtschaftsrecht (EuZW) 2012:650 et seq.

Kortmann J, Swaak C (2012) Private Antitrust Enforcement - Status Quo in the Netherlands. Europäische Zeitschrift für Wirtschaftsrecht (EuZW) 2012:770 et seq.

Koutsoukou G, Pavlova P (2014) Der Gerichtsstand der Streitgenossenschaft bei Schadensersatzklagen wegen Verletzung des EU-Kartellrechts. Wirtschaft und Wettbewerb (WuW) 2014:153 et seq.

Kriechbaumer C, Bamberger C (2014) Private Enforcement - Die Rechtslage in Österreich. Wirtschaft und Wettbewerb (WuW) 2014:690 et seq.

Krüger C (2013) Die haftungsrechtliche Privilegierung des Kronzeugen im Außen- und Innenverhältnis gemäß dem Richtlinienvorschlag der Kommission. Neue Zeitschrift für Kartellrecht (NZKart) 2013:483 et seq.

Lotze A, Smolinski S (2014) Einsichtsrecht der Zivilgerichte in Kartell-Akten. Entscheidungen zum Wirtschaftsrecht (EWiR) 2014:401 et seq.

Lurger B, Thiede T (2015) The international dimensions of law, 4th edn. Jan-Sramek Verlag, Vienna

Makatsch T, Mir AS (2015) Die neue EU-Richtlinie zu Kartellschadensersatzklagen - Angst vor der eigenen „Courage“? Europäische Zeitschrift für Wirtschaftsrecht (EuZW) 2015:7 et seq.

Mankowski P (2012) Der europäische Gerichtsstand des Tatortes aus Art 5 Nr 3 EuGVVO bei Schadenersatzklagen bei Kartelldelikten. Wirtschaft und Wettbewerb (WuW) 2012:797

Mansel H-P, Thorn A, Wagner R (2015) Europäisches Kollisionsrecht 2014: Jahr des Umbruchs. Praxis des Internationalen Privat- und Verfahrensrechts (IPRax) 2015:15 et seq.

Mäsch G (2003) Private Ansprüche bei Verstößen gegen das europäische Kartellverbot - „Courage“ und die Folgen. Zeitschrift Europarecht (EuR) 2003:825 et seq.

Mäsch G (2005) Vitamine für Kartellopfer: Forum shopping im europäischen Kartelldeliktsrecht. Praxis des Internationalen Privat- und Verfahrensrechts (IPRax) 2005:509 et seq.

Mederer W (2013) Richtlinienvorschlag über Schadenersatzklagen im Bereich des Wettbewerbsrechts. Europäische Zeitschrift für Wirtschaftsrecht (EuZW) 2013:847 et seq.

Menyhárd A (2014) Hungary. In: Karner E, Steininger BC (eds) European tort law (ETL). deGruyter, Berlin

Morony E, Jasper B (2015) England and wales. In: Mobley S (ed) Private antitrust litigation. Law Business Research, London

Motyka-Mojkowski M (2012) Die private Kartellrechtsdurchsetzung - Status Quo in Polen. Europäische Zeitschrift für Wirtschaftsrecht (EuZW) 2012:817 et seq.

Neethling J (2006) Toward a European ius comune in tort law, 2006 Fundamina 12-1:81 et seq. 
Peyer S (2012) Die private Durchsetzung von kartellrechtlichen Ansprüchen - Status Quo in England und Wales. Europäische Zeitschrift für Wirtschaftsrecht (EuZW) 2012:617 et seq.

Pfeffer U, Rummel P (2014) Die Zukunft privater Schadenersatzklagen nach dem Richtlinienentwurf der Kommission vom 11.06.2013. Wirtschaft und Wettbewerb (WuW) 2014:172 et seq.

Polster S, Steiner A-Z (2014) Zur Passing-on defense im österreichischen Kartellschadenersatzrecht. Österreichische Zeitschrift für Kartellrecht (ÖZK) 2014:43 et seq.

Rittenauer E, Brückner K (2014) Sonderschadenersatzrecht für Kartellgeschädigte, Wirtschaftsrechtliche Blätter. Zeitschrift für österreichisches und europäisches Wirtschaftsrecht (wbl) 2014:301 et seq.

Schuhmacher F (2014) Schadenersatzklagen im Wettbewerbsrecht - der Richtlinienvorschlag der Kommission. Zeitschrift für Wirtschaftsrecht (ecolex) 2014:193 et seq.

Schwab A (2014) Finding the Right Balance - the Deliberations of the European Parliament on the Draft Legislation Regarding Damage Claims, Journal of European Competition Law \& Practice (JECLaP) (2014) 5(2):65 et seq.

Schweitzer H (2014) Die neue Richtlinie für wettbewerbsrechtliche Schadensersatzklagen. Neue Zeitschrift für Kartellrecht (NZKart) 2014:335 et seq.

Spickhoff A (2009) Anspruchskonkurrenzen, Internationale Zuständigkeit und Internationales Privatrecht. Praxis des Internationalen Privat- und Verfahrensrechts (IPRax) 2009:128 et seq.

Spier J (2005) General introduction. In: European group on tort law, principles of European tort law. Springer, Vienna

Stauber P, Schaper H (2014) Die Kartellschadensersatzrichtlinie - Handlungsbedarf für den deutschen Gesetzgeber? Neue Zeitschrift für Kartellrecht (NZKart) 2014:346

Steiner A-Z (2013) Der neue RL-V der Kommission zum Private Enforcement, Zeitschrift für Wirtschaftsrecht (ecolex) 2013:1000 et seq.

Thiede T (2010) Internationale Persönlichkeitsrechtsverletzungen. Jan-Sramek-Verlag, Vienna

Thiede T, Sommer F (2015) Vorsätzliche Schädigung von Anlegern im europaweiten arbeitsteiligen Wertpapiervertrieb. Österreichisches Bankarchiv (ÖBA) 2015:175 et seq.

Urlesberger F, Ditz V (2013) EuGH kippt österreichische Regelung über die Akteneinsicht im Kartellverfahren. Österreichische Zeitschrift für Kartellrecht (ÖZK) 2013:135 et seq.

Vogel J (2012) Die private Durchsetzung des Kartellrechts - Status Quo in Frankreich. Europäische Zeitschrift für Wirtschaftsrecht (EuZW) 2012:897 et seq.

Vollrath C (2013) Das Maßnahmenpaket der Kommission zum wettbewerbsrechtlichen Schadenersatzrecht Neue Zeitschrift für Kartellrecht (NZKart) 2013:434 et seq.

von Bar C, Clive E (2009) Art VI-4:102, no 1-13. In: Study Group on a European Civil Code/Research Croup on EC Private Law (Acquis Group) (eds.), Principles, Definitions and Model Rules of European Private Law, Draft Common Frame of Reference (DCFR). Sellier, Munich

Weitbrecht A (2012) Schadensersatzansprüche der Unternehmer und Verbraucher wegen Kartellverstößen. Neue Juristische Wochenschrift (NJW) 2012:881 et seq.

Wurmnest W (2012) Internationale Zuständigkeit und anwendbares Recht bei grenzüberschreitenden Kartelldelikten. Europäische Zeitschrift für Wirtschaftsrecht (EuZW) 2012:933 et seq.

Yomere A, Kresken J (2014) Die Entscheidung des OLG Hamm zum Akteneinsichtsrecht von Zivilgerichten in Bonusanträge und vertrauliche Kommissionsentscheidungen. Wirtschaft und Wettbewerb (WuW) 2014:485 et seq.

Zimmermann R, Kleinschmidt J (2007) Prescription: framework and problems concercing damages claims. In: Koziol H, Steininger BC (eds) European tort law. Springer, New York

Zöttl J, Schlepper L (2012) Die private Durchsetzung von kartellrechtlichen Schadensersatzansprüchen Status Quo in Deutschland. Europäische Zeitschrift für Wirtschaftsrecht (EuZW) 2012:573 et seq. 